\title{
EN BØN TIL KROPPEN
}

Når medarbejdere mærker efter med mindfulnessmeditation

\author{
MARIANNE VIFTRUP HEDEGAARD
}

„Sæt dig godt til rette med fødderne solidt plantet i underlaget. Ret ryggen, så du făr en lang og lige rygsøjle. Mærk dine fødder, dit fundament, og find dit åndedræt. Prøv så, om du kan give slip på tankerne og bare være med din krop i de næste ti minutter." Det er torsdag morgen i et kursuslokale i indre København. Vi, de andre 11 kvinder i rummet og jeg, er på et opfølgningskursus for øvede i mindfulness. Jeg som antropolog på feltarbejde, de andre som vidensarbejdere og ansatte ved et dansk universitet, hvor mindfulness tilbydes som del af en håndfuld kurser for personlig udvikling og mental sundhed. Dagens første meditationsøvelse er netop gået i gang, og underviseren, Agnete, guider os ned i venstre fod og ud i tæerne. Hun opfordrer os til at mærke storetåen, lilletåen og tæerne imellem for så at mærke foden i dens helhed og dernæst takke den for dens hårde arbejde med at bære os rundt hele dagen. Længere oppe når vi venstre knæ. ,Måske mærker du ubehag,“ foreslår Agnete. „Du kan sende en tanke til dit knæ: Må mit knæ finde velbehag."Vi bevæger os videre gennem kroppen med lukkede øjne. Først venstre så højre side, fra neden og op. Lår, hofter, mave, hjerte, arme, skuldre, hoved. Velvære i kroppen bliver mødt med taknemmelighed og ubehag med venlighed og accept. Øvelsen kaldes en kropsscanning, og alle deltagerne i rummet har prøvet det gentagne gange det forgange forår på et introducerende mindfulnesskursus. „I kropsscanningen smelter vi kroppen,“ understreger Agnete og opfordrer os til at „give slip“, idet hun guider vores opmærksomhed til skuldrene, dernæst nakken og ansigtet. Til sidst skal vi forsøge at mærke toppen af hovedet. „Her, inde under huden, ligger hjernen med milliarder af celler og forbindelser, der arbejder for os hver dag. Måske har du lyst til at sige tak til hjernen?" De eventuelle taksigelser udtrykkes lydløst. Jeg sidder på min stol med en veltilpas varme, ro og afslappethed i kroppen. Agnete slår meditationsskålen an for at indikere, at meditationen er slut, og langsomt lukker vi øjnene op. 
Min deltagelse i Agnetes kursus var en del af mit ph.d.-feltarbejde udført i årene 2016-2019 på to danske arbejdspladser, hvor jeg undersøgte, hvordan og hvorfor buddhistisk inspirerede meditationspraksisser som mindfulness anvendes på det danske arbejdsmarked. Meditationer som den, jeg gengiver herover, udgør kernen i mindfulness, og som det illustreres i Agnetes valg af ord og fremgangsmåde, er sådanne meditationer fyldt med talehandlinger, anmodninger og taksigelser, som på den ene side minder om afspændingsøvelser, på den anden side minder om bøn. I denne artikel lader jeg mig inspirere af antropologisk arbejde, som har defineret bøn som et socialt fænomen og praksis, hvorigennem tro praktiseres og skaber moralske fællesskaber (Bandak 2017; Henkel 2005; Keane 2008), samt af tekster, som forstår bøn som ritualiserede former for kultivering af selv, sensibilitet og etisk rettethed (Hirschkind 2011; Mahmood 2012). Grundlæggende for tekster som disse er tanken om, at bønspraksisser er virksomme; at de konfigurer den, der beder, på nye måder i forhold til både himmel og jord samt egen krop og selv. Det, der bedes om i bønnen, fortæller os ikke alene om individuelle ønsker, men udtrykker håb og ønsker for et større fællesskab (Bandak 2017:5). Bønsteorier i den antropologiske faghistorie er som oftest udviklet med baggrund i religiøse praksisser og med fokus på monoteistiske traditioner. Mindfulness, derimod, betragtes og beskrives i en dansk sammenhæng som sekulær og tilbyder en interessant indgang til studier af grænserne mellem det religiøse og det sekulære, da mindfulness samtidig har sit grundlag i buddhistiske meditationspraksisser. Denne artikels formål er beslægtet med andre studier, som har undersøgt, hvad der kendetegner det såkaldt sekulære og den sekulære krop, og spurgt, hvilke praksisser denne kultiveres gennem (Asad 2011; Hirschkind 2011; Scheer, Fadil \& Johansen 2019). Jeg forstår her „,det sekulære“ som en social og kulturel formation og den sekulære krop som multipel. Der findes altså ikke én sekulær krop, men særlige forståelser og fremstillinger af kroppen associeret med det sekulære, som relaterer sig til forskellige akser som køn, race, alder og klasse (Scheer, Fadil \& Johansen 2019:1, 7). ${ }^{1}$ I tilgift til de mange værker om religiøs sensibilitet og praksis mangler vi, som påpeget af Charles Hirschkind, en større forståelse af det sekulæres ,sociale ontologi“ og undersøgelser af, hvilke praksisser, sensibilitet og viden der er inkluderet i denne (Hirschkind 2011:644). ${ }^{2}$ Jeg vil derfor inspireret heraf spørge, hvad der skabes af sensibilitet i en sekulær mindfulnessmeditation. For at undersøge dette stiller jeg skarpt på den mindfulde krop, og hvad det vil sige at blive bedre til at moerke efter gennem kropsarbejde i mindfulnessmeditationer.

Artiklen viser, at i mindfulnessmeditation er kroppen både medium og mål. Mindfulnesspraksisser som kropsscanning forsøger ikke blot at afslappe, men at indstille kroppen på en særlig etisk-affektiv måde, som tillader mindfulness- 
udøvere at skabe forbindelse med sig selv og omverdenen på en hensigtsmæssig måde. Kursisterne træner en sensibilitet, som gør dem i stand til at mærke efter uden at lade sig mærke for meget med det, de mærker. Det er ikke et kropsligt arbejde, som skal rette deltagere mod en transcendental sfære eller guddom. Det skal hjælpe deltagere med at være til stede på en rolig, afslappet og nærværende måde i den profane hverdag, de er en del af. Kursisten på et mindfulnesshold kan ikke være sikker på, at kropsscanning og mindfulnessøvelser vil gøre hende mindre stresset og rolig, men gennem disse praksisser anmoder hun kroppen om at falde til ro i en bøn til kroppen. At give slip, som Agnetes opfodring lyder i det indledende afsnit. Dette meditative arbejde bliver særligt interessant i en arbejdspladssammenhæng, hvor en sådan etisk-affektiv attitude - at kunne mærke efter uden at lade sig mærke - er med til at sikre medarbejderens fortsatte virke $i$ et presset arbejdsmiljø.

\section{Mindfulness: mainstreammeditationslære og globaliseret stress- middel}

Mindfulness er i de seneste tre årtier blevet mainstream. Folkekirken, folkeskoler og fødeklinikker inviterer til mindfulness til fremme af henholdsvis fordybelse, koncentration og smertelindring. Jobcentre, kommuner og virksomheder tilbyder mindfulness til dem, der er stressede over job eller mangel på samme. ${ }^{3}$ Agnetes kursus for universitetsansatte er således et blandt mange mindfulnesskurser, som tilbydes over hele Danmark. Mindfulness er oversat fra det centrale buddhistiske begreb sati, men har gennemgået adskillige oversættelsesprocesser, der har bragt praksissen i nye sammenhænge, således at mindfulness i dag er behæftet med et væld af betydninger (Cassaniti 2018). Der er derfor stor forskel på danske mindfulnesskurser, deres varighed og intention, omend de generelt er kendetegnet ved et mål om større trivsel og kropsligt velvære snarere end religiøs transformation (Borup 2016:13). Hvor nogle kurser handler om professionel udvikling og eksempelvis empatisk ledelsesstil (se fx charlottemandrup.com), retter andre kurser sig primært mod stressforebyggelse (se fx åbenogrolig.dk), mens andre igen ser mindfulness som et element i personlig udvikling og spirituel indsigt (se fx henningdaverne.dk).

Den store danske interesse for mindfulness afspejler en global tendens til at anvende og implementere mindfulnessteknikker som terapi mod et væld af mentale og fysiske lidelser gennem mindfulnessprogrammer rettet mod samfundsgrupper og institutioner også uden for religiøse ordener og fællesskaber (Gleig 2019; Stanley 2012; Stanley \& Kortelainen 2019; Wilson 2014). Fælles for disse programmer er, at de i større og mindre grad trækker på buddhistiske praksisser 
og forståelser af krop, sind og kosmos, samtidig med at de erkender sig ikke-religiøse og søger legitimitet i neurovidenskab frem for religiøse skrifter (Cook 2017; Eklöf 2016). Den amerikanske molekylærbiolog Jon Kabat-Zinn har lagt kimen til mange af disse programmer med udviklingen af stressreduktionsprogrammet Mindfulness-Based-Stress-Reduction (MBSR) i 1979. Mindfulness, som det praktiseres i disse programmer, sigter at placere sig langs en sekulær akse frem for en religiøs for, som Kabat-Zinn siger, at blive taget seriøst og ikke skræmme folk væk. Samtidig understreger Zinn i forskellige reflekterende artikler, at hans modernisering af mindfulness altid har haft som mål at ,gøre dharmaen mainstream" (Kabat-Zinn 2011:281). Mindfulness befinder sig således i grænselandet mellem det sekulære, det religiøse og det spirituelle og inviterer derfor til en opmærksomhed på grænsedragningerne imellem disse sfærer.

Mindfulness er ikke religiøs, fortæller mindfulnesskursister og mindfulnessundervisere mig. Så hvad adskiller en mindful kropsscanning fra andre kropsafslappende praksisser som fysioterapeutisk eller psykomotorisk afspænding, kunne man spørge. I mit feltarbejde blev mindfulnesspraksis ofte positioneret imod religiøs praksis, fordi det er videnskabeligt beviseligt, at det virker. Det er altså ikke et spørgsmål om at tro på effekten af meditation, men at vide, at det virker med henvisning til et stigende antal kontrollerede kliniske studier. Tilsyneladende tilbyder mindfulness alligevel mere end beviselig afslapning. Mindfulnesskursister beskriver mindfulness som en ny bevidsthed eller nyt perspektiv på livet, og flere sammenligner mindfulnessmeditation med bøn, som de kender fra religiøse sammenhænge. Ruth beskriver eksempelvis, hvordan Agnetes mindfulnesskursus for hende bliver en moralsk påmindelse om at være et godt menneske, hvilket minder hende om barndommens søndagsgudstjeneste, „bare uden al den snak om helvede“. Interessant er det i øvrigt at observere, at mindfulness, på trods af eller måske netop i kraft af sin etiket som sekulær, formår at fusionere med religiøse praksisser, såsom når den danske folkekirke afholder mindfulnessgudstjenester, eller når muslimer opfordres til at udføre șalât med en mindful attitude. ${ }^{4}$ Mindfulness virker til at have en evne til på trods af sin proklamerede sekulære status at intensivere inderligheden i religiøs bøn. Ifølge direktør for Dansk Center for Mindfulness Lone Fjorback handler mindfulness dog om etik, social retfærdighed og samfundsøkonomi og ikke religiøs overbevisning (Fjorback 2021). Fjorback peger mere konkret på mindfulness som en effektiv og økonomisk fordelagtig terapi til det stigende antal danskere, der lider af stress, depression og angst og derfor sygemeldes (Fjorback \& Pallesen 2016). Mindfulness er ikke bare gavnlig for det enkelte individ, mener Fjorbacke, men for folkesundheden og den nationale økonomi. Inden for mindfulnessforskning er der en voksende kritisk litteratur, der interesserer sig for konsekvenserne af Kabat- 
Zinns og andres reformulering af mindfulness fra en buddhistisk funderet praksis til ikke-religiøs og universel tilgængelig stressteknologi (Arat 2017; Purser 2019; Purser \& Milillo 2015.) Det er ikke mit ærinde her at diskutere, hvorvidt mindfulness er eller bør defineres som sekulær eller religiøs, men at pege på, hvordan den kropslige disciplinering i mindfulness udgør et interessant eksempel på en etisk-affektiv bearbejdning af kroppen mod en særlig sensibilitet.

\section{Hvad kendetegner en mindful krop, og hvordan opnås den?}

Hvad kendetegner den mindfulde krop ifølge mindfulnessfortalere? Den kendes ved et særligt forhold mellem den individuelle krop og det kollektive samfund. Lad mig komme med et kort aktuelt eksempel. Ligesom der i løbet af 2020 har været teletransmitterede gudstjenester grundet coronapandemien, hvor religiøse autoriteter som pave Frans har bedt for menneskeheden (Gallagher 2020), har mindfulnessautoriteter inviteret til fællesmeditationer, åbne for alle med internetadgang. På den populære amerikanske mindfulnessunderviser Tara Brachs hjemmeside finder man således en samling meditationer navngivet „Pandemic Care Resources", som Brach definerer som veje til ro, overblik og åbenhjertet tilgang i en global krisetid. Brachs videoer ses typisk af over 100.000 mennesker på verdensplan, hvilket indikerer, at mindfulness ikke blot er en fragmenteret, individuel praksis og del af forskellige kursusforløb, men også for mange praktiserende er et større organiseret hele med hierarkier, forbilleder og praksisfællesskab. I et interview understreger Brach, at den rolighed, man opnår gennem meditation, „,smitter“, og at mindfulnessmeditation derfor kan afdæmpe kollektiv angst $i$ en tid, hvor det meste af verden er blevet angst på samme tid (Samuel 2020). Ligesom viruspartikler kan smitte, kan affektive kropslige tilstande som ro og panik smitte, synes Brach at sige. Hendes udsagn udspringer af ekstreme tilstande, men illustrerer en grundlæggende antagelse i moderne mindfulnesspædagogik - nemlig, at meditationsarbejde starter i den individuelle krop for derefter at påvirke det kollektivt pulserende samfund. Det indadvendte arbejde er således socialt udadrettet (se også Pagis 2019), fordi meditation ikke blot beroliger det individuelle parasympatiske nervesystem, men ydermere kultiverer iboende etiske egenskaber som empati, åbenhed og nysgerrighed ifølge Brach og andre. Denne antagelse støttes af indsigter fra mit forskningsarbejde, hvor mindfulnesskursister ofte beskrev mindfulnessmeditation som en hjælp til at kunne indgå nærværende og helhjertet i sociale sammenhænge, hvilket modstrider ideen om moderne mindfulness som primært narcissistisk og indadvendt (se fx Purser 2019).

Hvordan opnår man større sensibilitet gennem mindfulness, er det næste spørgsmål - hvordan bliver man mindful? Agnetes måde at guide os gennem 
kroppen på og efterfølgende forklare dette kropsarbejde som en bearbejdning af instinktive impulser og en vej mod mere balance, kontrol og glæde afspejler, hvordan mindfulnessundervisning ofte udspiller sig. Mindfulnessundervisning er kendetegnet ved, at kroppen bliver genstand for både individuel undersøgelse gennem meditative øvelser og derefter kollektivt eftersyn, hvor kursisters oplevelse af tankemylder eksempelvis bliver forklaret og søgt afhjulpet gennem mindfulnessøvelser og de begreber, der findes i mindfulnesspædagogikken. Denne etisk-affektive disciplinering er rammesat på en særlig måde på den danske arbejdsplads, der som en sekulær arena er karakteriseret ved rationalitet og produktivitet, og dette dominerer undervisningens intention og målsætning. Samtidig søger mindfulnessundervisningen netop at bryde med en rationaliseret kropsforståelse, hvor tanker eksempelvis trumfer affektive fornemmelser. ,Folk i det moderne arbejdsliv cutter kroppen af," understreger Peter, en anden mindfulnessunderviser, en dag vi går tur rundt om søerne i København sammen. „De lever oppe i hovedet og glemmer at mærke efter. Det er derfor, de bliver stressede.“ Peter underviser blandt andet salgspersonale og farmaceuter i et stort medicinalfirma i mindfulness. Ligesom i Agnetes undervisning er det helt centralt for Peter, at de ansatte lærer at moerke efter $\mathrm{i}$ kroppen i stedet for at leve oppe i hovedet alene. I kropsscanning retter den mediterende således henvendelse mod krop, tanker og affektive fornemmelser for at mærke og møde spændinger og løsne dem gennem denne affektive opmærksomhed. For at uddybe, hvad det vil sige at mærke efter, og hvordan det kan forstås som en sekulær sensibilitet, vil jeg i det følgende lave en grundigere sammenligning mellem sekulær mindfulnessmeditation og religiøs bøn.

\section{Mindfulnessmeditation over for religiøs bøn: rettethed, formål og tidslighed}

Mindfulnessmeditation skaber på mange måder en interessant modsætning til bønspraksisser og meditation af religiøs og spirituel karakter. I fx chakrameditationer i spirituelt rettede yogapraksisser gennemgås kroppen, ligesom Agnete gør det, men forskellen er øvelsens formål og forestilling om dens virkning. I chakrameditation er toppen af hovedet - det, som Agnete henviser til som hjernen med en milliard neurale forbindelser - ofte beskrevet som kronen og adgangsbillet til en højere spirituel sfære. Målet er at balancere chakraerne, åbne kronechakraet og overskride kroppen for at forbinde sig til det, der kaldes brahman, universet eller altet (Hedegaard 2015). Modsat denne ide om overskridelse af kroppen stopper Agnetes kropsscanning ved kroppens kant, nemlig huden, der ligger hen over hjernen. I Agnetes kropsscanning markerer toppen af hovedet således krop- 
pens absolutte afslutning og afrundethed. Herunder ligger hjernen, som arbejder for os hver dag, understreger hun og opfordrer kursisterne til at rette en tak til hjernen. Sagt en smule forsimplet er kroppen i en mindfulnesssammenhæng ikke et medium rettet mod noget transcendent eller guddommeligt. Meditationen inklusive dens taksigelser og anmodninger er rettet mod kroppen i sig selv. Lad os prøve at komme nærmere, hvad der bliver bedt om og til i mindfulness ved at sammenligne yderligere med religiøs bøn eksemplificeret i Bruno Reinhardts studie af karismatiske kristne i Ghana (2017). I sammenligningen træder tydelige forskelle frem i forhold til bønnens rettethed, formål og tidslighed.

I sin undersøgelse af religiøs praksis i Ghana beskriver Bruno Reinhardt, hvordan pinsekirkelig spiritualitet beror på et præskriptivt apparat og sæt af praksisser, igennem hvilke et specifikt, religiøst subjekt frembringes gennem måder at tale på, moralske normer, en særlig tidslighed, performancegenrer (prædikener, profetier, tilbedelse) og spirituelle øvelser såsom faste og bøn (Reinhardt 2017:51). I Reinhardts beskrivelser bliver bøn en måde at være sammen med Gud på; i bønnen bliver man badet i Kristus. Bønner skaber således en tilstand af åndfuldhed, som blandt andet opstår, fordi de praktiserende har erhvervet sig evnen til at tale i tunger (op.cit.62) og derved blive bønfulde og spirituelt modnet (op.cit.55). Men hvad bliver man fyldt af gennem mindfulness? Sig selv? Hvad er det, man beder om, når man mærker efter, spænder af og siger tak til kroppen?

I de mange beskrivelser, jeg har lyttet til, af, hvad der sker, når man dyrker mindfulness, taler folk ikke om at blive opfyldt af sig selv eller noget andet. De taler derimod om, at mindfulness besvarer et behov for at blive tømt for tanker, lettet for tunghed, at få skabt rum til luft, at få luget ud. Alice på 35 beskriver eksempelvis, en dag hvor vi sidder på hendes kontor, hvordan hun gennem mindfulnessmeditation oplever at lindre sorgen over sit dødfødte barn, fordi meditationen får ,følelserne væk fra kroppen“. Sorgen, der for Alice sidder tungt i kroppen, bliver lettere at bære, når hun indimellem mediterer og derigennem rækker følelser ud i ,strakt arm“. Snarere end at blive fyldt op af en indre eller ydre kraft virker mindfulness til at skabe en form for positiv tomhed, en kærkommen stilhed og ro for Alice. Ydermere, hvor Reinhardt viser, at det at udvikle en bønspraksis og leve et liv i bøn kan være en måde at afstå fra verdens fristelser på, fx ved at bruge bøn til at overholde faste og cølibat, er mindfulness, som det blev beskrevet i mit feltarbejde, en måde at omfavne kroppens impulser og nuets sanselige potentiale på. En central øvelse i mindfulness er rosinøvelsen, hvor deltagere nærstuderer en rosin og træner deres sanser ved at betragte, smage og mærke på den. Den krop, der måske før havde svært ved at mærke efter, en effekt, mange oplever i forbindelse med stress, bliver gennem sådanne øvelser og meditation hjulpet til at genopdage sin sanselighed, mærke, smage, lytte, føle, 
dufte og i det hele taget åbne sig for verdens indtryk. Hvor Reinhardts informanter således bruger bøn til at forholde sig restriktivt til kropslige impulser og overholde kristne bud som faste og cølibat, bruger mindfulnesskursister kropsscanninger og meditationer til at åbne sig for kroppens signaler og sanselige indtryk og tage dem ind uden moralske vurderinger.

Reinhardt definerer bøn som en kropsliggjort færdighed og dyd, hvorigennem tro bliver en vane og et dagligt engagement, som fastholdes af det kontinuerlige bønsarbejde. Samtidig er et liv i bøn uafvendeligt et afventende liv, hvor løftet om Jesu genkomst eksempelvis skaber en særlig tidslighed, en tilstand af at leve $\mathrm{i}$ håbet og dvæle i Guds egen tid (Reinhardt 2017:70). En sådan produceret tidslighed igennem bøn er ikke begrænset til eksemplet med karismatiske kristne, men kendetegner i det hele taget mange bønspraksisser, som de øvrige artikler i dette temanummer også viser eksempler på. Interessant er det derfor at bemærke, at hvor religiøs bøn typisk rækker frem eller tilbage i tid, er mindfulnessmeditationer rettet mod nuet. I mindfulness er der ikke et afventende og håbefuldt eller angrende og afsonende element, snarere tværtimod, idet meditation og andre mindfulnesspraksisser orienterer sig mod det „nu“, der er lige nu. „Hvordan har du det lige nu? Hvad kan du mærke, sanse, høre? Hvilke tanker registrerer du lige nu? Hvilke følelser opstår der i kølvandet på disse tanker?" Det, der står helt centralt i mindfulnessmeditation, er altså kroppen og oplevelsen af kroppen, nuet og evnen til at mærke efter.

Men denne hengivelse til sansninger og kropslige impulser er kun hensigtsmæssig til en vis grænse ifølge megen mindfulnesspædagogik. Mindfulnesspraksisser søger nemlig samtidig at hjælpe deltagere med ikke at lade sig mærke af nuets indtryk og kroppens tilstand. Eller rettere, der er bestemte indtryk og kropslige fornemmelser, som ikke bør sætte deres varige aftryk. Derfor taler man i mindfulnessundervisning om at træne sig til et „teflonsind“, en attitude, hvor sanseindtryk, tanker og følelser bliver budt velkommen, fx i foden, men hvor samme indtryk bliver givet slip på eller forløst på den ene eller anden måde umiddelbart efter. „Sig tak til foden for dens hårde arbejde,“ som Agnete foreslår som en måde at forholde sig til smertefulde sansninger på. Det samme gør sig gældende for tanker og følelser. Hvis man mærker vrede under en meditationsøvelse, kan man hilse vreden velkommen og dernæst give slip igen. Sådan en bevægelse illustreres ofte med et billede af en himmel med hvide skyer. Vreden indtræffer som en sky på en himmel, og den mediterendes opgave er at lægge mærke til skyen velvidende, at himlen konstant forandrer sig og snart igen er blå. Skyen er forbipasserende, og derfor bør den ikke gøre varigt indtryk. Man skal moerke efter, men ikke lade sig moerke unødigt af vreden, smerten eller glæden. „Feel it, heal it. Name it, tame it”, som et ofte brugt mindfulness idiom lyder. 
Mindfulnesspraksisser indeholder således - ligesom religiøse bønspraksisser - det, jeg kalder en etisk-affektiv disciplinering, det vil sige ideer om og kropsarbejde rettet mod, hvordan man er et godt og balanceret menneske og til størst gavn for sig selv og andre. Men hvor religiøs bøn ofte indebærer en rettethed mod en ydre instans, som placerer den bedende på en særlig måde også i forhold til fremtid og fortid, er mindfulnessmeditation som oftest kendetegnet ved at rette sig mod kroppen i sig selv og mærke det nu, som er, og gennem introspektivt arbejde at afstresse og acceptere kroppens og nuets forhold. Som nævnt indledningsvis er der mange forskellige måder at definere og dyrke mindfulness på, og nogle vil givetvis være mere spirituelt og måske endda religiøst rettede. I det næste afsnit vender jeg tilbage til kursuslokalet og Agnetes undervisning for netop at illustrere det komplekse vidensapparat, mindfulnessundervisning bygger på, hvor referencer til buddhisme, neurovidenskab og psykologi blandes og virker sammen.

\section{Monkey mind: Hvordan mindfulnessundervisning afmærker krop- pen gennem sproglige begreber og visualiseringer}

'Hvorfor er mindfulness vigtigt?' Agnete ser spørgende ud på os og peger mod det sammenklipsede sæt af printede PowerPoint-slides, vi alle har fået uddelt som supplement til timen. 'Fordi vi har en vandrende hjerne. En monkey mind.' Der rynkes et par bryn rundt om bordet, og hun skynder sig at koble monkey mind med et mere velkendt ord: stress. Agnete, som er uddannet erhvervspsykolog, forklarer, at monkey mind er, når vores hjerne løber af med os, hvilket hænger sammen med vores stressrespons. 'Hjernen scanner omgivelserne efter trusler, selvom den slet ikke behøver at gøre det. Det er det, der kaldes default modenetværk. Men vi behøver ikke være ofre for vores biologi. Vi kan vælge at træne vores opmærksomhed - med mindfulness.' Agnete uddyber sin pointe ved at beskrive, hvordan menneskets forfædre havde gavn af hjernens trusselsapparat. Det var smart at udskille store mængder adrenalin, når man skulle kæmpe imod eller løbe fra farlige dyr på savannen. 'Det er derimod ikke særlig smart i vores arbejdsliv anno 2019 at reagere på det, der truer os, ved at løbe væk eller slå fra sig.' Holdet ler, mens hun maler et billede af medarbejderen, der enten giver sig til at slås eller løber skrigende væk, når chefen kommer med nye opgaver.

Jeg gengiver denne scene fra mit feltarbejde, fordi det ikke kun er selve det at sidde i meditation, der skaber en mere mindful krop. Det forståelsesapparat, som mindfulnessundervisere tilbyder, er også et vigtigt element i det etisk-affektive arbejde mod en mindful krop, som fx når koncentrationsbesvær beskrives som et udtryk for menneskets monkey mind. Agnete griber ikke udtryk som monkey mind ud af den blå luft. Sådant et udtryk er del af et rigt vokabularium, som 
iværksættes under mindfulnessundervisning for at forklare eksempelvis processer i hjernen, stresstilstande eller meditationsteknikker. Første gang, jeg fik identificeret min hjerne som en monkey mind, sad jeg på feltarbejde i det nordlige Indien og lyttede til en yogaguru, som guidede mig og omtrent 50 andre gennem klassisk yogafilosofi. Der er langt fra yogaskolen i Indien til kursuslokalet i indre København, men begreber som monkey mind forbinder forskellige meditative praksisser som hatha yoga og mindfulde kropsscanninger på tværs af landegrænser og kulturelle kontekster. Hvor den indiske guru primært beskrev monkey mind i form af en lignelse, en historie om en abe, der forsøger at få en banan op af en krukke, aktualiserede Agnete begrebet monkey mind ved hjælp af et hypermoderne ord fra neurovidenskaben, default mode-netværk. Det er typisk for mindfulnesspædagogik, at begreber fra buddhistiske og hinduistiske praksisser, yogafilosofi, psykologi og neurovidenskab blandes (Eklöf 2016), og det er netop undervisernes evne til at koble „østens visdom“, som underviseren Peter kalder det, med evidensbaseret fakta, der fascinerer mange deltagere. Begreber som monkey mind og default mode-netværk er med til at afmærke den mediterendes krop og skabe nye forståelsesrammer for, hvad det er, vi mærker, når vi mærker efter, og hvordan vi skal reagere på det. Hvordan reagerede deltagere så på fx at høre om monkey mind og default mode-netværk? Ruth beskrev, hvordan begrebet default mode-netværk var blevet et referencepunkt, som hjalp hende til at identificere, når hun var uopmærksom. Alice tog også taknemmeligt nye begreber fra mindfulness til sig og definerede mindfulness som noget, ,der mangler i Vesten, hvor vi er blevet religionsløse og leder efter mere indhold i vores tankegang og vores liv, som Østen måske stadig har“. Ruth og Alice udgør et eksempel på en generel trend blandt mindfulnesskursister til at omfavne mindfulness som værdifuld, både fordi, som Alice udtrykker det, det fremsættes som videnskabeligt „,beviseligt“, og fordi religionen er „taget ud af det“, samt fordi det dertil tilbyder en ekstra komponent, som nogle definerer som spirituel, andre livsfilosofisk og andre igen som østlig eller antik visdom. For Ruth og Alice var det dog den oplevede effekt, mindfulnesspraksis havde på deres følelsesliv og kropslige velvære, der gjorde den særligt værdifuld. For Ruth blev mindfulnesspraksis en måde at håndtere stress på arbejdspladsen i forbindelse med fyringsrunder og centralisering på (se også Hedegaard 2020b). For Alice blev meditationsøvelserne en måde at bearbejde sin sorg på ved få „følelserne væk fra kroppen“, hvilket i første omgang kan lyde kontraintuitivt. Undervisere som Agnete opfordrer netop deltagere til at sanse nuets oplevelser med de tanker, følelser og kropslige fornemmelser, det indebærer. For Alice blev sådanne sanseøvelser imidlertid en måde at sortere i virvaret af følelser på og skille dem ad og holde dem ud i strakt arm. Ved at gå ind i følelserne, sanse, mærke sig selv gennem øvelser 
som skyøvelsen kunne hun fx identificere følelsen af skyld, og gennem en accept af skyldfølelsen og et fokus på åndedrættet og kropslige fornemmelser forsøgte Alice at lade følelsen af skyld passere forbi uden at lade den dominere hendes følelsesmæssige tilstand.

Når Alice fortæller mig om sine oplevelser af at få følelserne væk fra kroppen, samt hvordan mindfulness hjælper hende i samværet med sin fireårige datter, og hun samtidig understreger den generelle vigtighed af mindfulness for meningsfuldheden i et vestligt ikke-religiøst liv, fortæller det os noget om den komplekse virkning, mindfulness kan have på dagskursister som Alice. For Alice handlede mindfulness i høj grad om at lære den hårfine balance mellem at mærke sig selv og ikke lade sig mærke for meget med, hvad hun møder i meditation, hvad end det er skyldfølelser, vrede, glæde eller afmagt. Dette er ikke mindst vigtigt i arbejdslivet, understreger Alice, hvor hendes evne til at sige „pyt“ er vokset med mindfulnesstræningen. I det følgende vil jeg vende tilbage til nogle empiriske eksempler fra min felt og beskrive forbindelsen mellem selve det at træne at mærke efter med konteksten og baggrunden for dette sansearbejde, nemlig den danske arbejdsplads.

\section{Meditationens virkning og kontekst: Hvorfor dyrke mindfulness på arbejdspladsen?}

En af de første gange, jeg var med til Agnetes undervisning, bad hun det pågældende hold om at danne en rundkreds. Forinden havde alle kursister valgt et billede fra en stor bunke postkort på et bord i midten af kursuslokalet. Billedet skulle illustrere den pågældende kursists intention med mindfulness. „Spørg dig selv, 'hvorfor er jeg her?'“var Agnetes opfordring. Folks intentioner med mindfulness var rørende, personlige og dybfølte. Særligt en af billedbeskrivelserne gjorde indtryk på mig. Det var Olivia, en HR-medarbejder, som havde valgt et billede af en murstensvæg tagget med sort graffiti. I midten af det mørke inferno af tags tittede et lille felt af pink frem. Olivia beskrev, hvordan hendes arbejdssituation føltes som dette sorte virvar. Endnu en omstrukturering havde skabt uro og usikkerhed, og hun og hendes kollegaer vidste ikke, hvad fremtiden bragte, om de fx skulle flyttes til en anden afdeling, eller om de overhovedet kunne beholde deres job. Det var en tung atmosfære, der trak hende ned, forklarede hun. Hendes ønske med at lære at meditere var at finde en måde at holde sig oven vande på. Hun ville være det lille stykke pink, der ikke sank midt i det sorte kaos. „Jeg tror, det er derfor, jeg er her, “ sagde Olivia. „For at arbejde med mig selv." Olivia har tidligere i sit liv været syg med stress, og beslutningen om at prøve mindfulness var derfor også en del af et forsøg på at undgå at blive stresset igen. 
Under mit feltarbejde kæmpede jeg med at finde forbindelsen mellem det kropsnære arbejde, som vi udførte i fx kropsscanninger, og relevansen i dette arbejde for de travle kontorer, folk derefter tog tilbage til. Hvordan kan det være, at det at mærke efter med mindfulness var blevet en ingrediens i opskriften på at undgå stress? I denne artikel er det kun muligt at fortælle en lille del af den historie ved at fokusere på den sensibilitet, mindfulnessøvelser er med til at kultivere (se også Hedegaard 2020a). Som jeg beskriver ovenfor, er denne sensibilitet kendetegnet ved en øget sanselighed og opmærksomhed på øjeblikkets sensoriske indtryk samt på ens egen krop og dens signaler. Samtidig er denne sensibilitet kendetegnet ved evnen til at lade øjeblikkets ubehag som ophobet stress, frustration og tankespind opløse sig som skyer på en himmel. Det er netop opøvelsen i at sanse „de små ting“, som Agnete siger, fuglenes lyde, kaffens duft og følelsen af et kram, som kan hjælpe med at give slip på ,de store ting“ som den tunge atmosfære på arbejdspladsen. I Peters og Agnetes undervisning er det mindre relevant, hvilke omstændigheder der har bragt medarbejdere i en stresstilstand. Fokuspunktet er, hvordan det meditative arbejde kan hjælpe udøverne af mindfulness med at forholde sig til udfordringer, stress og pres på arbejdspladsen snarere end at forandre forholdene.

Ud over timerne i Agnetes kursuslokale tilbragte jeg meget tid i et medicinalfirma, hvor underviseren Peter guidede adskillige hold ansatte i mindfulnessmeditationer i ti ugers forløb designet i samarbejde med firmaets HR-afdeling. For medicinalfirmaet var mindfulnessforløbet et led i en optimeringsproces, hvor personalet skulle „løbe stærkere“, som Susan, HR-chefen, sagde. Forhåbningen var, at mindfulness kunne hjælpe medarbejdere med at håndtere stress og utilpashed i løbet af arbejdsdagen ved at lave korte meditationer, tjekke ind og mærke efter. På den måde var både produktivitet og trivsel sikret gennem den særlige sensibilitet, mindfulness forhåbentlig kunne fostre - en sensibilitet over for kroppens faresignaler og nuets potentiale. Da forløbet for de 84 tilmeldte medarbejdere blev evalueret, blev medarbejderne gennem 32 spørgsmål i et spørgeskema spurgt, om de oplevede, at de var blevet bedre til at lytte til sig selv, være nærværende og mere tilpasse gennem mindfulness. Ledelsen evaluerede ikke arbejdspladsens forhold i de mange spørgsmål, men udelukkende, hvorvidt den enkelte medarbejder havde været i stand til at blive mindful.

Andre forskere har beskrevet denne måde at placere ansvaret for arbejdsstress hos den enkelte medarbejder på som en neoliberal tendens og konsekvens af New Public Managements indtog på det danske arbejdsmarked (se fx Willig 2016; Sørensen 2015). Hvor Willig og Sørensen fokuserer på medarbejderes oplevelse af ikke at kunne ytre sig frit og kritisk på arbejdspladsen, har jeg i mit arbejde fokuseret på arbejdspladsens invitation til, at medarbejdere øver sig i at 
mærke efter, en invitation, som måske hænger sammen med den forstummede kritik. I stedet for at kritisere omstændighederne inviteres medarbejdere til i stilhed at mærke efter, hvordan det høje tempo påvirker dem. På den måde kan HRchefen Susan, som bekymrer sig om medarbejdernes ve og vel, imødekomme det uomtvistelige faktum, at der er risiko for at opleve stress, når man løber stærkere, uden at skulle ændre på den realitet, at tempoet skal skrues op. Hun kan opfordre folk til at mærke efter i løbet af dagen, mens de løber stærkere, groft sagt. Man kan derfor forstå evnen til at mærke efter uden at lade sig mærke med det som en særlig sekulær sensibilitet, der er opstået, i takt med at arbejdspladser er blevet underlagt selvstyring, større pres, konkurrence og prekære forhold. På den måde bliver mindfulnessmeditation en bøn til kroppen om at slappe af i små mellemrum i løbet af dagen og lade stress og jag prelle af. Det bliver en bøn til kroppen, hvor det ikke er en ydre instans, der formildes eller søges ændret, men derimod de tanker, følelser og smerter, der opstår i kølvandet på en presset situation. Kultiveringen af en sådan sensibilitet balancerer på en knivsæg. Medarbejderne opfordres til at blive bedre til at mærke efter og mærke sig selv, men de skal også være i stand til ikke at lade sig mærke med eksempelvis uro i forbindelse med nye opgaver eller udfordringer. Historisk set er der ikke noget nyt $i$, at sensibilitet må balanceres, at man både må være i stand til at mærke efter og være mådeholden med at mærke sig selv for meget. Lad mig i det følgende afsnit uddybe denne pointe ved at inddrage Talal Asads forståelse af den sekulære krop samt hans tanker om smerte og sensibilitet.

\section{Mærk efter: mindfulness som et balancerende arbejde mod en sekulær sensibilitet}

Asad bruger smerte som indgang til at undersøge, hvad der konstituerer den sekulære krop og beskriver, at smerte i det såkaldt sekulære samfund - modsat det religiøse - er privatiseret, og at man her søger kausale forklaringer på smerte. Smerte må bevises i en meningsfuld biologisk sammenhæng, sådan som Agnete faktisk gør det i kølvandet på den kropsscanning, hun instruerer. Når vi bliver stressede og oplever smerte og symptomer som koncentrationsbesvær, søvnmangel og forhøjet blodtryk, skyldes det neurologiske strukturer i hjernen og instinktive biologiske reaktionsmønstre, forklarer hun. De fysiske smerter, funktionsforstyrrelser og følelsesmæssige frustrationer, som har drevet vidensarbejdere på mindfulnesskursus, forklares af Agnete med henvisning til hjernens processer, hvad der ifølge Asad er typisk for en sekulær tilgang til kroppen og kroppens smerte. ${ }^{5}$ Hvad der alligevel er så interessant i Agnetes kropsscanning som beskrevet i starten af artiklen, er den religiøst velkendte måde, hvorpå hun 
anmoder kroppen om at balancere disse kropslige ubalancer. „Må mit knæ finde velbehag, "siger hun eksempelvis. Sådan en formulering minder om formuleringer i kristen bøn, hvor Jesus fx citeres for at sige: Må I finde velbehag i mig. Det religiøse sprog, som Agnete blander ind i meditationen, komplicerer kropsscanningen som en udelukkende sekulær aktivitet og tilfører også, i min egen erfaring, en inderlighed til den ellers profane kropspraksis, som slutter med at takke hjernens milliard celleforbindelser. Mindfulnesspraksis både bekræfter og taler imod Asads tese, at smerte i et sekulært samfund er privatiseret. I det kursuslokale, hvor jeg blev undervist af Agnete, var der til en vis grad plads til både psykisk og fysisk smerte. Det var naturligt at opleve fysisk og psykisk smerte, og kursister bekendte deres smerte over for hinanden. Samtidig bearbejdede vi smerten ved at vende os indad, mærke os selv, i stedet for at tale om de strukturer og omstændigheder, der frembragte smerten. Vi anmodede i fællesskab vores egen krop om afslapning. Mindfulnesskurset åbnede på den måde for en mindre privatiseret tilgang til smerte, men samtidig blev smerten ikke anerkendt som andet end individuelle sansninger og tanker.

Asad har i sine refleksioner over den sekulære krop henvist til historiske forskelle mellem dydig sensibilitet og hysteria med reference til Patricia Spacks beskrivelse af sensibilitet i starten af 1800-tallet. I Spacks analyse af begrebet hysteria viser hun, at hvor en vis grad af sensibilitet var et godtaget udtryk for det private selvs taktfulde følelser, nemlig at være i stand til at føle andres lidelse, var hysteria dets modsætning. Det at mærke efter, både på andre og sig selv, medfulgte sociale sanktioner eller bifald. At være tilpas sensibel blev anset som en nobel egenskab, hvorimod hysterisk sensibilitet var anset som grænseoverskridende og selvoptaget og en perversion af sensibilitet (Asad 2011:666). I Asads beskrivelse af den sekulære krop i vor tid bruger han figurer som „hypokonderen“ og ,den hysteriske“ som eksempel på karakterer, der mærker for meget de mærker noget, som ikke kan bevises - mens den sensible medfølende person mærker tilpas til at føle sympati for sine medmennesker på en hensigtsmæssig måde. Centralt i mindfulness er et lignende balancerende arbejde mod at genopdage kroppens smerter og sanselighed, at mærke efter og at være sensibel, ikke bare for at hjælpe sig selv til at få det fysisk og mentalt bedre, men også for at åbne sig mere for resten af verden. For at blive taget alvorligt i en sekulær sammenhæng skal den arbejdende krop dog være balanceret sensibel - i stand til at mærke efter, men samtidig ikke lade sig mærke for meget med omstændighederne. Når jeg siger, at det er et balancerende arbejde, er det, fordi det netop ikke må blive hypokondrisk eller hysterisk. HR-chefen Susan illustrerede denne pointe godt, da hun beskrev sin bekymring forud for mindfulnesskurset i medicinalfirmaet. „Man kan jo også komme til at tale for meget om stress. Lige pludselig så 
har alle stress, bare de mærker en smule ondt i maven." For Susan var mindfulness også en teknik til at mærke efter, hvornår man havde det godt, og en mulighed for at lune sig ved succeser på arbejdspladsen. Mindfulness skulle således ikke bare være en opmærksomhed mod det affektivt problematiske, men også det glædelige „rush“, som arbejdet kan give.

Det at kunne mærke efter er ikke blot i arbejdssammenhænge, men i det hele taget $i$ det danske samfund en dyd, som debatteres som en balancegang. „Mærk efter!“ lyder titlen i læge Jesper Bay Hansens bog med taglinen: „,Det er ikke altid nemt at mærke efter, så det bliver gjort, men ikke overgjort. Selvregulering er kodeordet, både når vi mærker indad og udad“ (Bay-Hansen 2015). „Stop med at mærke efter" lød det mere konsekvente budskab fra Svend Brinkmann i den bog, der gjorde ham til Danmarks måske mest prominente forsker (Brinkmann 2014). Sådanne opfordringer til at mærke efter, men ikke mærke for meget efter er blevet populære som et forsvar mod individualiserende tendenser i tiden. Det menneske, der mærker for meget efter, er selvcentreret, endda ynkeligt og offer for en selvrealiseringstrend (Abrahamsen 2014). Gennem mindfulnessøvelser arbejder medarbejdere mod en særlig sekulær sensibilitet, at være i stand til at mærke efter uden at mærke for meget, og på denne måde indgå produktivt og glædesfuldt $i$ et hektisk arbejdsliv, uden at, som Olivia sagde, synke ned i kaos. Det sekulært sensible og mindfulde menneske har altså situationsfornemmelse, fingerspidsfølelse og selvkontrol og udviser etisk takt ved at mærke tilpas meget efter. At kunne mærke sig selv uden at mærke for meget blev for Olivia, Ruth og de mange andre kursister en måde at blive i arbejdslivet uden at få stress.

\section{Konklusion: den mindfulde medarbejder}

I denne artikel har jeg undersøgt, hvad der er på spil, når medarbejdere mærker efter med mindfulnessmeditation. Jeg har vist, at hvor den bedende i religiøs bøn som oftest henvender sig til en almægtig anden, henvender den mediterende $\mathrm{i}$ mindfulness sig til egen krop for at bede om afslapning, afstresning og ro. For at undgå, at medarbejdere rammes af stress, hjælpes medarbejdere gennem mindfulness netop til at mærke sig selv og afkode kroppens signaler. Gennem dette sansede arbejde instrueres kursister også til at lære at give slip på det, de mærker. Hvor religiøs bøn, illustreret i Reinhardts eksempel fra Ghana, disciplinerer den bedende til at fordybe sit forhold til Gud og blive badet i Kristus, beskriver mindfulnesskursister effekten af mindfulness som stilhed, tomhed, lethed, ro. Jeg har beskrevet det arbejde, som kursister på mindfulnesskurser udøver, som en kultivering af en sekulær sensibilitet. Det gør jeg med henvisning til den pågående debat inden for antropologiske og religionssociologiske studier, som interesserer 
sig for, hvad en religiøs kontra en sekulær krop kan være. I de 37 interviews, jeg lavede med vidensarbejdere i forskellige funktioner i mit ph.d.-feltarbejde, var der en klar tendens til, at det at meditere indebar et håb om at kunne forblive $\mathrm{i}$ jobs, der bød på hård konkurrence og højt tempo, og som krævede fuld dedikation fra den enkelte trods omstrukturering, overarbejde og uforudsigelig fremtid. Jeg argumenterer derfor for, at den særlige sekulære sensibilitet, der udvikles gennem mindfulness på arbejdspladsen, hænger tæt sammen med nutidens arbejdsmarkeds krav om fokus, fleksibilitet, selvstyring og robusthed i arbejdslivet. Den mindfulde krop og dens sekulære sensibilitet er både kendetegnet ved rationaliseret mådehold og hengiven nydelse af nuets indtryk, og mindfulnessmeditation er et eksempel på, at den måde, vi mærker os selv på, og den måde, vi mærker andre på, ikke blot er en intuitiv, biologisk om man vil, evne, men en orkestreret aktivitet, hvor moralske idealer og samfundsnormer er iblandet. Mindfulnessøvelser bliver hermed en bøn til kroppen om at nyde nuets goder, give slip på følelsen af stress og pres og indgå åbent, roligt og fokuseret $\mathrm{i}$ arbejdslivet.

\section{Noter}

1. Scheer, Fadil og Johansen undersøger, inspireret af Asad, det sekulæres ,grammatik“ (Asad 2011:673) og forstår det sekulære i relation til bredere historiske baggrunde, politiske omstændigheder og kulturelle fænomener som noget, der praktiseres, opleves og mærkes (Scheer, Fadil \& Johansen 2019:1, 7).

2. Charles Hirschkind har i sine analyser af kassettebåndsgudstjenester i Egypten vist, hvordan muslimske mænd søger at udvikle dyder som beskedenhed, ydmyghed og gudsfrygt. Hirschkind argumenterer for, at kroppen nødvendigvis må kultiveres på lignende måder i såkaldt sekulære sammenhænge, og efterspørger analyser af dette (Hirschkind 2011).

3. Religionssociolog Jørn Borup har med udgangspunkt i Aarhus påvist en eksplosiv stigning af mindfulnessudbydere på 75 procent fra 2012 til 2015 (Borup 2016:13).

4. „How to be mindful in Salah”, https://amuslimmama.com.

5. Andrea Muehlebachs analyser af frivillighed i den italienske region Lombardiet tilbyder en anden interessant diskussion af smerte og sekulær sensibilitet (Muehlebach 2012), hvor det at udvikle en sensibilitet over for sit indre, ,at se med hjertet", ses som nødvendigt for at blive sensitiv over for andres lidelse. Ulig Asads analyse af, at smerte er privatiseret i det sekulære samfund, viser Muehlebach, hvordan det at genkende andres smerte, det, hun kalder ,the technique of cosuffering", fungerer som forudsætning for sekulært, etisk medborgerskab i Italiens smuldrende velfærdsstat (op.cit.120). 


\section{Litteratur}

Abrahamsen, Sebastian

$2014 \quad$ Hold op med at mærke efter i dig selv. Dagbladet Information 22.9.

Arat, Alp

2017 What It Means to Be Truly Human. The Postsecular Hack of Mindfulness.

Social Compass 64(2):167-79. https://doi.org/10.1177/0037768617697390.

Asad, Talal

2011 Thinking about the Secular Body, Pain, and Liberal Politics. Cultural

Anthropology 26(4):657-75. https://doi.org/10.1111/j.1548-1360.2011.01118.x.

Bandak, Andreas

2017 The Social Life of Prayers. Introduction. Religion 47(1):1-18. https://doi.org/

10.1080/0048721X.2016.1225904.

Bay-Hansen, Jesper

2015 Mærk efter! København: Mindspace.

Borup, Jørn

2016 Mindfulness as a Booming, Diverse and (Non) Religious Phenomenon-Mapping and Analyzing Mindfulness in the City of Aarhus. Religion i Danmark 7(2):1-16.

Brinkmann, Svend

2014 Stå fast. Et opgør med tidens udviklingstvang. København: Gyldendal Business.

Cassaniti, Julia

2018 Remembering the Present. Mindfulness in Buddhist Asia. New York: Cornell University Press.

Cook, Joanna

2017 Mind the Gap. Appearance and Reality in Mindfulness-Based Cognitive Therapy.

In: D. McMahan \& E. Braun (eds): Meditation, Buddhism, and Science.

New York, NY: Oxford University Press.

Eklöf, Jenny

2016 Saving the World. Personalized Communication of Mindfulness Neuroscience.

In: R. Purser, D. Forbes \& A. Burke (eds): Handbook of Mindfulness. Mindfulness in Behavioral Health. Cham: Springer International Publishing.

Fjorback, Lone O.

$2021 \quad$ Hvad er problemet? Weekendavisen 14.1.

Fjorback, Lone O. \& Johanne Pallesen

20165 grunde til, at vi skal træne vores mentale sundhed. Dagbladet Politiken 2.8 .

Gallagher, Delia

2020 Pope Francis Prays for a Coronavirus Miracle at "plague" Crucifix Church.

CNN: https://www.cnn.com/2020/03/16/europe/pope-francis-prayer-coronavirusplague-crucifix-intl/index.html. Læst 15.4.2020.

Gleig, Ann

2019 American Dharma. Buddhism Beyond Modernity. New Haven \& London: Yale University Press.

Hedegaard, Marianne Viftrup

2020a Mindful Work. An Etnography of Mindfulness and the Sociality of Feeling in Danish Workplaces. Ph.d.-afhandling. København: Institut for Tværkulturelle og Regionale Studier, Københavns Universitet. 
2020b The Mindful Gardener and the Good Employee. Mindfulness Practice and Affective Labor in the Danish Workplace. In: T. Brox \& E. Williams-Ørberg (eds): Buddhism and Business. Merit, Material Wealth, and Morality in the Global Market Economy. Honolulu: University of Hawai'i Press.

2015 Mellem omsorg og optimering. Et antropologisk studie af etiske tilblivelsesprocesser og daglig disciplin blandt yogaudøvere i Rishikesh. Speciale. København: Institut for Antropologi, Københavns Universitet.

Henkel, Heiko

2005 Between Belief and Unbelief lies the Performance of Salat. Meaning and Efficacy of a Muslim Ritual. Journal of the Royal Anthropological Institute 11(3):487-507. https://doi.org/10.1111/j.1467-9655.2005.00247.x.

Hirschkind, Charles

2011 Is there a Secular Body? Cultural Anthropology 26(4):633-47.

https://doi.org/10.1111/j.1548-1360.2011.01116.x.

Keane, Webb

2008 The Evidence of the Senses and the Materiality of Religion. Journal of the

Royal Anthropological Institute 14(s1):S110-27. https://doi.org/10.1111/j.1467-

9655.2008.00496.x.

Mahmood, Saba

2012 Politics of Piety. The Islamic Revival and the Feminist Subject.

Princeton: Princeton University Press.

Muehlebach, Andrea

2012 The Moral Neoliberal. Welfare and Citizenship in Italy. Chicago: University of

Pagis, Michal Chicago Press.

2019 Inward. Vipassana Meditation and the Embodiment of the Self. Fieldwork Encounters and Discoveries. Chicago: The University of Chicago Press.

Purser, Ronald

2019 McMindfulness. How Mindfulness Became the New Capitalist Spirituality.

London: Repeater.

Purser, Ronald \& Joseph Milillo

2015 Mindfulness Revisited. A Buddhist-Based Conceptualization. Journal of

Management Inquiry 24(1):3-24. https://doi.org/10.1177/1056492614532315.

Reinhardt, Bruno

$2017 \quad$ Praying until Jesus Returns. Commitment and Prayerfulness among

Charismatic Christians in Ghana. Religion 47(1):51-72. https://doi.org/10.1080/

0048721X.2016.1225907.

Samuel, Sigal

2020 "Our Calm Is Contagious". How to Use Mindfulness in a Pandemic. Vox 18.3.

Scheer, Monique, Nadia Fadil \& Birgitte Schepelern Johansen (eds)

$2019 \quad$ Secular Bodies, Affects, and Emotions: European Configurations.

New York: Bloomsbury Academic.

Stanley, Steven

2012 Mindfulness. Towards A Critical Relational Perspective. Social and

Personality Psychology Compass 6(9):631-41. https://doi.org/10.1111/j.1751-

9004.2012.00454.x. 
Stanley, Steven \& Ilmari Kortelainen

2019 Assembling Mindful Bodies. Mindfulness as a Universal "Laboratory of Practice". In: S. Salmenniemi (ed.): Assembling Therapeutics. Cultures, Politics and Materiality. Abingdon, Oxon \& New York, NY: Routledge.

Sørensen, Pelle Korsbæk

2015 Moralsk stress. En arbejdslivsanalyse af psykisk arbejdsmiljø, deltagelse og retfærdiggørelsesprocesser blandt højtuddannede vidensarbejdere i Danmark. Ph.d.-afhandling. Roskilde: Roskilde Universitet.

Willig, Rasmus

2016

Afvæbnet kritik. København: Hans Reitzels Forlag.

Wilson, Jeff

2014

Mindful America. Meditation and the Mutual Transformation of Buddhism and American Culture. Oxford: Oxford University Press. 